\title{
Locating authenticity
}

\section{The Politics and Poetics of Authenticity: A Cultural Genealogy of Sinhala Nationalism by Harshana Rambukwella (London: University College London Press, 2018, 164 pages)}

\author{
Reviewed by Neloufer de Mel* \\ Department of English, Faculty of Arts, University of Colombo, Colombo, Sri Lanka.
}

A popular idiom has it that "there are many ways to skin a cat". If that cat was nationalism, one would have thought that in academic analysis, it had already been skinned in numerous ways, given the significant scholarship and debate the topic has generated in Sri Lanka, particularly since 1983. Harshana Rambukwella has, however, found a compelling angle to the story of Sinhala Buddhist ethno-nationalism (arguably the most important vector of nationalist discourse in Sri Lanka for its far-reaching impact) that has never been told in quite the same way before. That angle is authenticity - as an analytical category and register of discourse. Rambukwella defines it as a "punitive discourse" of inclusion and exclusion (p. 6), "protean, mobile and hard to pin down" (p. 19). It shares affinities with other units of analysis that we have heard before - whether of border and borderlands, hybridity, making and unmaking, narrativising, the politics of such and such, or constellations and contestations. So, what does authenticity bring to the conversation that is different, what does its deployment enable its author, and importantly, where most titles stop at the politics of something, why does Rambukwella title his book The Politics and Poetics of Authenticity?

Rambukwella answers my last question throughout the book: "authenticity is a structure of feeling, deep seated and affective" (p.10). It is a trope that permits him to look in depth at culture as ideology and practice. The book draws on a variety of cultural events and products spanning from the late $19^{\text {th }}$ century to the contemporary: from songs sung "wrong" (a reference to the row over an operatic rendering of Danno Budunge at Independence Day 2016), to memoirs, political speeches and short stories of S. W. R. D. Bandaranaike; the speeches, letters and writing of Anagarika Dharmapala collected in The Return to Righteousness; the semiautobiographical writing of Martin Wickramasinghe; short stories by Gunadasa Amaraskera and Liyanage Amarakeerti; the theatre of Sugathapala de Silva and Gamini Haththotuwegama and Jothipala's pop songs, to name the most significant examples that Rambukwella cites. The author's ability to reference these with lucidity to illustrate his arguments indicates both rigorous scholarship and a valuable familiarity with a rich and wide-ranging cultural history of Sinhala writing, music, aesthetic thought and discourse in Sri Lanka.

The emphasis on poetics also reflects and enables the author to write with empathy on the "problem" that is authenticity in the story of Sri Lankan nationalism: a difference in tone that is new and important. Authenticity in this book is the site of ambivalence and mourning. Even if we repudiate it, thick histories of aesthetic work and scholarly debates are evidence that creative writers, scholars, politicians and public intellectuals have, and continue to grapple with its promise. As Rambukwella writes, its potential, in postcolonial contexts, is "the belief that there is a domain of life that lies outside colonial modernity" (p. 151), an inner, prior core which is the place of authenticity. It thereby

"Corresponding author (neloufer@english.cmb.ac.lk)

This article is published under the Creative Commons CC-BY-ND License (http://creativecommons.org/licenses/ by-nd/4.0/). This license permits use, distribution and reproduction, commercial and non-commercial, provided that the original work is properly cited and is not changed anyway. 
drives both romanticisations of the past and sophisticated postcolonial deconstructions of western epistemologies. Rambukwella warns, however, that there is a fine line between the critiques of western assumptions on the one hand, and of nativism on the other for the binaries they invite. Furthermore, through an astute discussion of the deep structural relationship of authenticity to nationalism (p. 149), authenticity's construction and use by iconic figures in Sri Lankan history and literature, and its work in producing a mourning for something irretrievably lost, Rambukwella sets up authenticity for an empathetic critical reading that refuses to summarily dismiss it as false consciousness or instrumental tool.

What does authenticity as an analytical unit enable in this book? It provides the author a framework under which three figures pivotal in Sri Lankan history and Sinhala culture (Anagarika Dharmapala, S. W. R. D. Bandaranaike and Gunadasa Amarasekera), each of whom constructed and deployed authenticity in ways that thereafter became "essential" to the national narrative and imagination, are brought together. It also provides an umbrella under which Rambukwella conjoins the overlapping trajectories and commentaries of his three main characters. For example, Return to Righteousness, the seminal Dharmapala text, gets compiled and produced during the 1950s, its habitus the swing to swabhasha and Sinhala Only, of which, Bandaranaike is a main exponent (even though it was Dudley Senanayake who actually launched Dharmapala's book) (p. 68). Again, Gunadasa Amarasekera wrote extensively on Dharmapala, a discourse Rambukwella keenly analyses. Therefore, not only are these figures assessed in their own right, but also contextualised in relation to each other's work in a manner that points not only to coincidence and contingency but also the durability of authenticity. Its effects on contemporary developmental discourse and policy, electoral rhetoric, religious extremism, and the failures of institutional reform and peacebuilding are cases in point.

The author's framing of authenticity as umbilically linked to the story of nationhood also provides a platform from which to critically reflect on the scholarship, so far, on Sinhala Buddhist nationalism. The book's very useful introduction presents a summation of why and how this subject gains traction in Sri Lankan scholarship. July 1983 is marked as the watershed event, considered as particularly important for both the political and scholarly turn to nationalism, including the latter's engagement with key postcolonial theories on the topic. This marks the beginning of what Rambukwella calls methodological nationalism, or an orientation towards nationalism as a normative subject of inquiry and analytical frame (p. 8).
I found this to be one of the most useful points in the book because, how this methodological orientation frames each of the case studies retrospectively as nationalist leaders, Buddhist ideologues, and "authentic" conveyors of an organic culture and so on, alerts us to the need to situate our own methodologies in their own specific histories. This is something Rambukwella does assiduously for the concept of authenticity itself, by charting its course within Sinhala Buddhist nationalism, and historicising its sources including its legacies in a sociology of the rural that identified the tank, paddy field and Buddhist temple as nodal points. He also does so by asking questions about why nationalists turn to authenticity (implying that nationalism can be prior, or independent of authenticity), how and why it shifts during their own lifetimes, and why the nationalist "father figures" selected for inquiry in the book become "reconstituted as iconic figures of authenticity in post-independence Sinhala nationalism" (p. 20).

The three figures foregrounded in this book-Dharmapala, Bandaranaike and Amarasekera - construct and use authenticity in various ways. Yet for each of them it marks an inner need, a way of identifying and becoming, legitimising themselves in relation to the Sinhalese as a people, as a vote base, as readers. Rambukwella offers a compelling analysis of each of his "father figures", and of how authenticity is imagined, reified, instrumentalised and/or revisioned in their work. He also forewarns that many of the reference points through which authenticity was articulated by this trio have now passed their sell by date and become "tired signifiers," "over-used", no longer enjoying the same caché in the public imagination (p. 23). There is an argument here that the validity of authenticity as a concept is not over for the Sinhalese- after all the book begins with the row over how and why Danno Budunge was sung in coloratura operatic style (a debate which showed that the idea of authenticity is alive and well), but that its old metaphors of the rural, the farmer, the deeply Buddhist ethos of the village, and the achievements of ancient Sinhala kingdoms have lost their edge, particularly for today's youth (p. 137). The decline is dated to the Gam Udawas of the Premadasa era which, for Rambukwella, brought kitsch and popular culture to the village in the guise of Sinhala pop stars such as Jothipala and fairground rides (he forgets the army tattoos) that commodified the village and dealt a death blow to authenticity that had up until then been associated with the "high culture" of subhawitha sangeethaya or semi classical Sinhala song, and the songs and voices of Amaradeva and Nanda Malini. 
One problem in writing about authenticity, a concept that is not passive but does the work (both subtly and overtly) of inclusion and exclusion, is that its inner and outer boundaries constitute a slippery line. In other words, being always outside of it is not easy. For instance, to say something is kitsch or pastiche in a particular tone can be heard as a judgement about aesthetic values. Or to say that Dharmapala has been framed retrospectively as a nationalist figure may sound like an argument for a retrieval of an "authentic time". For the most part, however, Rambukwella is aware of his own positionality - for none of us occupy neutral ground, and he does this by historicising his subject and subjects as much as he can. The lapses in this regard, therefore, are very few. More serious is that, given his argument that authenticity is aligned to purity and preservation, it is somewhat surprising that Rambukwella has not paid much attention to gender: a primary site on which purity, preservation and reproduction are constructed. The author does refer to the importance of the Ariya Sinhala woman (via a citation of my own work) in the trajectory of authenticity within Sinhala ethno-nationalism, and to Dharmapala's assessment of the colonized Sinhalese as an emasculated public, but these are in passing. I have no problem with his selection of the three "father figures" - for their legacies have been profound. But they are themselves ripe for a serious, sustained, gendered analysis. Rambukwella's study so far generates many such future possibilities, and for what it currently offers by way of a cogent, largely empathetic analysis of the role of authenticity within Sinhala nationalism, The Politics and Poetics of Authenticity marks an important scholarly contribution to the many ways in which the nation can be narrated. 